\title{
Library and Information Science Education: Preparing Librarians for a Multicultural Society
}

\section{Claudia J. Gollop}

For more than a decade, the demographic prognosticators have been saying that the racial, ethnic, and cultural makeup of the United States is on the verge of a major shift; and that not long after the turn of the new century, segments of the population that had previously been in the minority will collectively become the majority, with Hispanics being the largest minority group. The implications of such an unprecedented event have prompted private- and public-sector institutions to question whether they will be equipped to work with their "new" constituencies. Schools of library and information science (LIS) are not exempt from such selfexamination and must make every effort to prepare all their graduates to work in larger multicultural environments. However, such preparation may mean altering several courses in a school's curriculum. These kinds of changes are likely to meet with greater success when all parties involved, both inside and outside the classroom, hold a committed and vested interest in the reorganization efforts. This article discusses issues of diversity in LIS education programs and how these efforts can be addressed positively to better serve students and their future users.

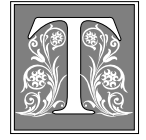

he demographic projections of a significant increase in the proportion of nonwhite population segments are well known and have been linked with almost every aspect of life in the United States. Spanning the range from education to business and industry to health care, serious considerations of the impact on society have been under way for some time. What fuels this sense of urgency? One response might be the fact that such a shift in the racial and ethnic composition of this nation's populace is simply unprecedented. For example, it is anticipated that Hispanic Americans will emerge as the nation's largest minority group, removing African Americans from that long-held position. ${ }^{1}$ Added to this is the prediction of the nearly explosive increased number of older adults (persons over the age of sixty-five) who will have a significant, influential socioeconomic impact on the coming decades. ${ }^{2}$ In addition, it can be expected that more persons who are physically and learning challenged will enter mainstream society as more facilities and institutions improve the level of compliance with the edicts of the Americans with Disabilities Act of 1990.

Another, or related, response may be that there is a sense of the unknown. Will

Claudia J. Gollop is an Assistant Professor in the School of Information and Library Science at the University of North Carolina at Chapel Hill; e-mail: gollop@ils.unc.edu. 
a change in, for example, the proportion of older persons and/or a transformation, to some extent, of the complexion of much of the country really be very consequential to its day-to-day operation? If not, things can go on as usual and there is no need to do anything very differently. If so, what types of practices and programs can be put in place to respond to those growing segments of our population? Leaders in the public and private sectors of society are wondering whether they will be ready to "deal" with this new America. Where, then, does this leave LIS education and librarianship as a whole?

\section{Generally, for example, African- American librarians were assigned to work only within the black commu- nity.}

Fortunately, the LIS profession may have an advantage over some other fields and disciplines. In the past, libraries in many parts of the country, like most of the nation's institutions, did not escape segregation and discriminatory practices. However, libraries, particularly those located in larger cities, have always served diverse user groups. For example, in the early part of this century, public librarians in New York City held programs for the flood of new immigrants, most of whom did not speak English fluently. ${ }^{3}$ In the late 1960s and the 1970s, when the focus was on those segments of society deemed to be socially and economically disadvantaged, libraries responded with outreach efforts that would attract new patrons. The availability of federal funds, particularly those from the Library Services and Construction Act (LSCA), helped to support, among other things, the education and training of librarians who would serve these groups and to "assist states in the improvement of library service for physically handicapped, institutionalized and disadvantaged persons, and to strengthen major metropolitan libraries." ${ }^{4}$ Recent history shows that several initiatives directed toward certain patron groups or specific types of service have met with success. However, a more comprehensive approach, which would combine lessons from the past with enhanced communication across the profession, would result in a better-served public. Although many factors play important roles in the delivery of service, two elements in particular remain central to whether and how well the LIS profession will respond to a rapidly increasing multicultural society. The administrative divisions, within both LIS education and library and information organizations of all types, must renew the commitment to improve service outcomes for all user groups with a focus on the growing multicultural population.

\section{From Whence We Came}

The formal education for professional librarians began in 1887 at the School of Library Economy at Columbia College in New York City. ${ }^{5}$ Before that time, most, if not all, librarians were trained during apprenticeships on location. Also, the vast majority of library personnel were men. Clearly, diversity would have meant something very different at the end of the nineteenth century than it does todaymost notably, the introduction of women to the newly established field of library science. The School of Library Economy was a contrivance of Melvil Dewey, noted author of the Dewey Decimal Classification system, and the site of the first women enrolled in the new program for librarians.

Some have speculated on Dewey's motives for recruiting women into the program at Columbia College. It does appear that he had both personal and economic interests in bringing women into the program. Michael $\mathrm{H}$. Harris testifies to Dewey's enigmatic nature when he writes:

His almost mystical influence over his followers, the unremitting hatred evidenced toward him by his enemies, the charges against him of anti-Semitism, his strange and controversial involvement with (and 
influence over) women, and his ruthless and often questionable entrepreneurial schemes, all contribute to his reputation as one of the most complex figures in the history of librarianship. ${ }^{6}$

It is true that Dewey has been criticized as much as praised on several issues. However, he did introduce the concept of formal education for librarians and realized it while recruiting women to the field, albeit at lower salaries than received by their male counterparts. Says Wayne A. Wiegand, "although he did not say it, Dewey was, he believed, setting an example for the rest of librarianship; he was recruiting a work force with high character for low cost."7 However justified Dewey may have felt, to be sure the introduction of women caused quite a stir on Columbia's campus at the time. Several decades later, the introduction of African Americans and other persons of color on America's college and university campuses was met with similar reactions. Change is never easy, and it can be made even more difficult when it is unanticipated and its aspects misunderstood. This point is further illustrated by Wiegand, who points out the lack of diversity in the founding of the first professional librarians' organization in this country. He reflects on the organizers of the first ALA convention, which was held in early October 1876 in Philadelphia. Describing the designers of ALA who were prompted by Dewey and very enthusiastic about launching the new organization, Wiegand writes:

While they marched forward with conviction, however, they failed to recognize they were also products of a socioeconomic and cultural value system in which they had been raised and educated. All ALA officers were white, Anglo-Saxon Protestant males born in the Northeast. Most were educated in northeastern schools; most were reared in middleclass or upper-class families. ${ }^{8}$
In the years to follow, the nation and the profession would witness slow, but persistent, change as persons of diverse racial and cultural backgrounds entered the field, although not always welcome and often with restrictions. Generally, for example, African-American librarians were assigned to work only within the black community. It would be even longer, not until the 1960s, before defined methods aimed at increasing the number of minorities in the field were enacted, the result of federal legislation. As activist visionaries such as E.J. Josey and Clara Stanton Jones agitated for greater inclusion and improved library services to black communities across the country, change did begin to occur.

In 1970, Robert Wedgeworth, who later became executive director of the ALA (1972-1985) and dean of America's first school of library science education, contemplated the dearth of black presence and influence in the profession. He wrote:

\section{If librarianship is to be a rewarding profession for black American(s), one must assume that the opportu- nity to practice it also involves the opportunity to shape the principles and practices which define it. Cer- tainly the lack of a visible career lad- der is likely to be a formidable bar- rier to the recruitment of black Americans, especially males. ${ }^{9}$}

The purpose of this brief history is merely to create a context of the times, as unfortunate as they may have been for many, in which persons of color were neither encouraged nor largely accepted into this profession just as they were not welcome to join many other fields. Just as access to education for librarianship was beyond the reach of men and women of color during the early days of the profession, library science faculty positions were even more unattainable for nonwhite segments of the population.

It was, of course, a very noteworthy accomplishment for that period in library science history that the first library sci- 
ence faculty post held by an African American was in 1904 at the Western Reserve University (later renamed Case Western Reserve University). That position was held by Edward Christopher Williams. Nonetheless, even though the number of blacks to hold faculty positions has increased since 1904, it is far from being representative of the AfricanAmerican population in the United States. Even more remarkable is the fact that the segment of the population least represented within LIS education in the nation happens to be American Indians. This is somewhat ironic given the fact that they are descendents of the original peoples of this land. Presently, fewer than five American Indians hold full-time faculty positions at schools of library and information science. ${ }^{10}$

\section{Attracting more persons of diversity to doctoral programs poses the greater challenge on several levels}

It is encouraging, though, that the relationship of male to female LIS faculty at all ALA-accredited programs has approached a nearly 1:1 ratio for well over a decade. ${ }^{11}$ However, the figures for faculty members of underrepresented groups (African Americans, Hispanic Americans, Asian and Pacific Island Americans, and American Indians) have not seen much change in more than thirty years. In 1993, Josey wrote:

If you carefully examine the ALISE annual statistics, you will find that blacks, Hispanics, Asians, and American Indians have not increased as a percentage of the entire population in library and information science education programs since the passage of the Civil Rights Act of $1964 .^{12}$

Although the number of nonwhite, full-time faculty in LIS programs is currently still quite small, according to the ALISE annual statistics, there has been an increase in the number of faculty from various racial and ethnic groups, from just under 13 percent in 1993 to 15.5 percent in 1996. ${ }^{13-14}$ However, diversity across the faculties of LIS schools does not reflect today's multicultural populations, a situation that may not bode well for the composition of future LIS faculty. It is a wellknown fact that many demographers predict that by the early decades of the next century, approximately one-third of the nation's population will be composed of persons of diverse backgrounds. Thus, a greater ethnic and racial imbalance could be created than exists presently if no significant increase occurs in those percentages. It is important that the LIS faculty of the future reflect the multicultural makeup of society and of the students enrolled in LIS programs.

Where will this increasingly multicultural LIS faculty come from? A powerful effort will have to be undertaken across LIS education if future faculty distribution is to even approach an acceptable ratio of diversity. As it stands, the ALISE statistics indicating doctoral degrees awarded in 1996-1997 show that six minority students were awarded doctorates by LIS schools in the United States. ${ }^{15}$ Among them, three were African American, two were American Indian, and one was Hispanic American. No Asian/Pacific Island Americans were reported to have been awarded doctorates during that period. Possibly, more encouraging are LIS doctoral student enrollment figures. ALISE reported that in the fall of 1995, 490 students were enrolled in LIS doctoral programs in the U. S. (This figure does not include international students, nor students enrolled in non-U.S. programs, such as Canadian LIS programs). Of the 490 , seventy-nine, or approximately 16 percent, were members of designated minority groups (37 African American, 20 Hispanic American, 19 Asian/Pacific Island American, and 3 American Indian). ${ }^{16}$

Although these figures may seem somewhat promising, as well they should, a note of caution also may be in order. For one thing, by comparison, en- 
rollment in a doctoral program requires a rather long-term commitment involving significant expense and possible relocation of family or long periods of separation from family (because not all LIS programs offer doctoral degrees, relocation becomes a genuine concern). Several other challenges influence the decision to enroll in a doctoral program, and some of those same challenges factor into how and when a student will complete the program. Many programs allow students approximately eight years to complete the degree; however, it is not uncommon to find that most institutions will grant extensions in the hope of assisting students to complete the process. Asecond consideration is that it is not known what, if any, percentage of those future LIS Ph.D.s of diverse backgrounds will seek faculty positions rather than administrative or other positions.

Thus, not only are the numbers of minority Ph.D. graduates consistently lower than those for white graduates and the dates for completion of doctoral programs, along with the availability of the new graduates, uncertain, but there also is no guarantee how many will choose careers as faculty in LIS education. Consequently, it is be very difficult to predict an increase in the level of diversity among LIS faculty.

Often during periods of intensified recruitment the profession as a whole will focus on prospective MLS students, resulting in some loss of attention on the recruitment of doctoral students to those schools that maintain such programs. Although the need for librarians at every level will always outnumber the need for LIS faculty, it also is clear that LIS educators will continue to be essential if those programs are to continue and prosper. Attracting more persons of diversity to doctoral programs poses the greater challenge on several levels, as stated above. Nonetheless, it is not one that is insurmountable. This needs to be addressed because the latter cohort is, most likely, the group who will be there to teach and advise a diverse student body.

\section{The Other Side of the Coin}

Understandably, most often, issues of recruitment and retention of underrepresented groups are among the first concerns voiced when LIS education and diversity are the topics of discussion. In addition, the focus usually centers on LIS education at the master's degree level, with less emphasis on the more advanced degrees. When one observes the current situation regarding diversity within LIS education, it may be helpful to view the issue as two sides of the same coin in need of a two-pronged strategy. That is, recruitment and retention efforts should be increased for students at both the master's degree level and doctoral level in hopes of filling vacated faculty positions. After all, approximately 30 percent of all fulltime LIS faculty were fifty-five years of age and older in 1996. This may mean that several schools will witness faculty retirements in the next ten years.

In terms of the recruitment of racial and ethnic minorities to LIS programs, the data indicate that over the past three decades, there has been a considerable increase relative to the proportion of MLS graduates from underrepresented groups who hold positions in all types of libraries. However, those gains have been the most gradual within the area of academic librarianship. The growth in the number of librarians from minority segments of the population has been the most visible within the public libraries of the nation. In 1991, the ALA issued Academic and Public Librarians: Data by Race, Ethnicity $\mathcal{E}$ $\mathrm{Sex},{ }^{17}$ in which it illustrated that 4.96 percent of all academic librarians were African American (486) and that nearly twice that number of public librarians $(7.25 \%$, or 965) were black. That same document furnished statistics for other racial and ethnic groups. It is interesting to compare the figures for the underrepresented groups with those of white librarians. American Indian/Alaskan Native librarians numbered only sixty-two $(0.63 \%)$ for academic libraries and twenty-nine $(0.22 \%)$ for public libraries, compared to Asian/Pacific Islanders, who numbered 
$485(4.95 \%)$ in academic libraries and 404 $(3.03 \%)$ in public libraries. One hundred and fifty $(1.53 \%)$ Hispanic librarians were in academic libraries, and 269 (2.02\%) were in public libraries. To contrast those figures, 8,618 $(87.93 \%)$ white librarians were at academic libraries, and 11,646 $(87.48 \%)$ held positions with public libraries. At the time of this writing, ALA had yet to update the survey. However, it is safe to say that observations and anecdotal evidence reveal that no significant statistical change has occurred relative to any of these groups working in either type of library.

It is important to employ some way of providing students with a better understanding of the library and information service needs of a multicultural society.

In libraries and information centers around the country, the roles and responsibilities of librarians are changing and, for the most part, LIS education is trying to keep pace. However, as the population shifts occur through the early decades of the next century, a better-educated, betterinformed populace will expect, if not demand, that library personnel, as well as personnel of other institutions, better reflect the diversity of the coming society. Since the early 1970s, there have been examples of impressive and successful recruitment strategies for increasing the percentage of underrepresented library professionals, as James C. Welbourne writes;

During the 70s, library education tried to take the leadership in redressing the imbalance which existed relative to the professional preparation of those who chose to work in urban-based public or academic libraries. Laudable efforts were mounted in the library schools at Columbia, Toledo, Wayne State, Rutgers, Illinois and Maryland. ${ }^{18}$

Other recruitment efforts such as that lead by E.J. Josey at the University of Pitts- burgh should be emulated if LIS education is to provide our nation's libraries and information centers with a multicultural workforce.

\section{Curriculum Issues: What Are We Teaching?}

It is important for all students enrolled in LIS programs to be exposed to issues of multiculturalism and diversity. Students with an interest in this area will usually self-select and enroll in courses that have a broader cultural perspective. It can be expected that students who do not necessarily hold such an interest will usually apply their precious credit hours to taking other courses. However, in many instances, upon graduation the latter students may find themselves ill prepared for encounters with library patrons who are very different from themselves. These graduates may possess little knowledge of how best to respond to and to bridge those differences. There are certain approaches that may be used to help maximize such outcomes, such as an entire course devoted to diversity issues in LIS education. Other possibilities include organizing units in a given course (e.g., reference, cataloging, collection development) around multicultural/diversity issues and inviting guest speakers to discuss topics such as collection development and gay and lesbian literature or concerns of library service and programming for older adults. Lorna Peterson suggests these and other strategies for infusing the LIS curriculum in an effort to reach the largest number of students. Also, Peterson makes the sound point that multiple efforts must be made concurrently if multicultural education in the LIS curriculum is to touch every student at some level during his or her program of study. This widespread approach is suggested, in part, because so few schools of library and information science offer full courses on diversity issues and so few faculty maintain a teaching or research focus in these areas. Says Peterson: 
Of the fifty-seven library schools listed in the Association for Library and Information Science Education 1993-94 Directory, sixteen schools list faculty with ethnic and cultural history as a specialty. Of the approximately 700 full and part-time faculty listed, 21 gave ethnic and culture history as their specialty. These small numbers suggest that library schools should be attempting a more organized and deliberate effort in multicultural education. ${ }^{19}$

At the University of North Carolina at Chapel Hill School of Information and Library Science, the author has introduced a course called Library and Information Services to Diverse User Populations (formerly called Library Services to Special Populations), in which the perspectives of various ethnic and cultural groups are examined. In addition, many of the situational circumstances in which the disabled (physically, visually, and learning), institutionalized, and older adults access information are studied. In many instances, legal and public policy issues relative to compliance influence services to these segments of the population. The Department of Library and Information Science at the University of Pittsburgh (School of Information Sciences) offers variations on the special populations course, entitled Resources and Services for Special Populations, which usually focuses on a specific group such as older adults or African Americans, depending on the instructor.

Another approach that LIS schools could take to ensure that exposure and insight relative to diversity issues are imparted to the student body is to provide schoolwide, regularly scheduled guest lectures or programs during which issues relative to the information and service needs of the various constituencies are examined and discussed. For example, students interested in a career in public services in academic libraries may be interested in a program focusing on international students and visiting schol- ars to whom the English language as well as American methods of teaching and learning and conducting research are unfamiliar. Each year, hundreds of thousands of these temporary residents find themselves on the campuses of our nation's colleges and universities and as users of those libraries. Regardless of the method, every graduate must be prepared to function in work environments that are composed of and serve persons of diverse backgrounds. It is important to employ some way of providing students with a better understanding of the library and information service needs of a multicultural society. This will only benefit new LIS graduates in the future.

Also, consideration must be given to those librarians and information specialists who have been practicing their craft for years. As the population changes, many already in the profession may profit from continuing education courses designed to strengthen their awareness of diversity issues relative to the provision of services and to other workplace concerns.

Deans and directors of LIS schools must face constantly the challenges of managing resources. For those institutions without comprehensive goals and objectives for improving diversity among students and faculty, it may appear particularly burdensome to add another dimension to an already-full agenda. However, it is critical that LIS education administrators exploit all available means in pursuit of such ends. Ultimately, the effects of those efforts will be positive and long term and will radiate out from the LIS schools to the various publics served by their graduates.

Improving the level of diversity in librarianship also is being approached on yet another level. Recently, the ALA undertook a bold and far-reaching enterprise that will have long-term results for the profession. ALA has created the Spectrum Initiative, a scholarship fund designed to provide financial assistance for students from underrepresented racial and ethnic groups who are enrolled in 
ALA-accredited LIS programs. The awards of $\$ 5,000$ each will help defray some of the costs of graduate education. Several LIS programs, as well as library systems and associations, have shown their support of the Spectrum Initiative scholarship program and the prospective graduates by agreeing to make additional financial commitments to the effort by either matching grants or supplementing them. The first fifty of the 150 scholarships to be given over a three-year period had been awarded, as of this writing. ${ }^{20}$ Among the LIS schools to make such a pledge are the School of Information and Library Studies at the University of Buffalo (SUNY), the School of Library and Information Science at the University of Wisconsin-Milwaukee in partnership with the Milwaukee Public Library, and Rutgers University Library and Information Studies Department, along with several others. It is hoped that programs such as the Spectrum Initiative will serve as a rallying call to others in the profession to participate in various recruitment approaches.

Of course, there is the time-tested method of meeting the demands for more professional librarians by "growing your own," which is usually done at the local level. For many years, large and mediumsized public library systems have used this tactic by forging an agreement with an area library and information school. For example, at the New York Public Library, library personnel who do not hold the MLS, but express an interest in librarianship, may attend classes in pursuit of the degree at Pratt Institute (located in Brooklyn, New York), under NYPL's tuition reimbursement policy. Other area public library systems (e.g., Brooklyn Public Library) maintain similar programs that have proved to be successful as well. In geographic areas that are as highly diverse as New York City, programs such as these perform an important function in the mission to provide library and information service to all communities by helping to create a library workforce that is reflective of all of society.

\section{Conclusion}

Hope may spring eternal, but more often than not, progress occurs in fits and starts. In the case of the advancement of diversity in LIS education, this author prefers to see the glass as being half full, which is to say that more people who represent a variety of racial, ethnic, and cultural backgrounds are enrolled in LIS programs and employed in the LIS professions today than in the past.

Issues of multiculturalism and diversity in LIS education is multidimensional and often holds different meanings for different people. Increasingly, and unfortunately, images and impressions bear nearly as much influence as reality. This can be particularly damaging if the images are negative or if those individuals encountered are perceived to be so different as to seem not to warrant attention or service. LIS educators must be cognizant of these unfortunate trends and incorporate information and clarity on such issues in their respective curriculums. Clearly, at the very least, the desire for better understanding and more tolerance of the differences among us must be communicated.

However, it will take more than the will and isolated nisus of LIS faculty alone. If the future workforce of the profession is to be representative of the racial and ethnic makeup of the nation, upper-tier administration must be dedicated to advancing institution-wide policies relative to multiculturalism and information access, from premise to practice. Certainly, many administrators are apt to face several challenges as they move toward accomplishing such a complex, though not hopeless, task. Nonetheless, the issue of diversity and the general response to it by LIS education and the profession is not new, nor has it been wholly welcome. For some time now, several professionals who are well acquainted with LIS education have expressed the need to broaden the curricular view within the library and information science programs (Josey 1993, 1991; Peterson 1994; Owens 1994; Abdullahi, 
1992). ${ }^{21}$ In response, some LIS educators have stated that they cannot teach everything, while librarians and information practitioners have asked how much more can they be expected to do? Given their usually crowded working agendas, both the statement and the question are valid and justifiable. Again, there must be a commitment to multicultural inclusiveness and the tone must be established by upper administration. To start the process, Veronica E. Nance-Mitchell suggests:

To promote diversity in the campus climate, administrators need to assess the situation, which should almost always begin with an institutional analysis and move to an environmental analysis. The assessment should revolve around diversity needs and the responses of each segment of the institution (administration, faculty, staff, and students). ${ }^{22}$

As stated earlier, concerns about multicultural diversity are not new nor are the many suggested solutions offered in the past and illustrated in this article. Presently, the major difference is that library and information science educators and administrators have long been alerted to the grand population shift that is coming and the potential political, economic, and social impact that may accompany it. How we respond this time is apt to be highly scrutinized. LIS schools have had a good deal of practice, and several examples of noble efforts exist. That experience, along with heightened awareness and a firm commitment to create more diversity within the profession, says that we should expect to see measurable and sustained success in the future.

A decade ago, in describing the necessity for an increased multicultural presence among library personnel, Kathleen M. Heim wrote:

We need more catalogers; we need more youth services librarians; we need more information services per- sonnel with science backgrounds and, to complicate the challenge, we need personnel in all areas to be more ethnically diverse than they are currently. ${ }^{23}$

Although much of the discussion of this article has focused on racial and ethnic determinations of diversity, it must be mentioned again that other population segments also must be included in the description of a dynamic and diverse citizenry. The fact that there are still fewer students enrolled in LIS programs and fewer positions held by either information practitioners or LIS educators with physical or visual disabilities, for example, illustrates the point that the profession as a whole has some work to do.

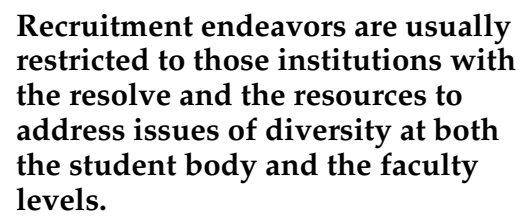

The work will not be easy. There are only fifty-six programs in North America with large areas having no schools of library and information science anywhere nearby ${ }^{24}$ Understandably, with so few LIS programs and the geographic distribution being what it is currently, somewhat of a burden has been placed on those existing programs to accommodate the students enrolled and to furnish as many of their educational requirements as possible. However, a part of that education should include exposure to and discussions of library and information service to all possible constituencies. For its part, LIS education will be asked to add more diversity to its ranks as well.

Recruitment endeavors are usually restricted to those institutions with the resolve and the resources to address issues of diversity at both the student body and the faculty levels. These efforts are often supported by one-time grants or otherwise very limited funding, not necessarily intended to sustain 
a long-term recruitment agenda, so as to allow a program to build on its own success. In the next century, possibly a combination of current models of attracting students and faculty to the field of library and information science with innovative methods of support will bring greater results.

Synergetic approaches to accepting and increasing multiculturalism and diversity in LIS education are necessary and welcome. Clearly, there is a need for administrators, educators, and practitioners in library and information science not only to communicate more, but also to form working coalitions that will enhance LIS curriculums and that are supportive of professional information specialists in the field as they work to better understand and serve a growing diverse constituency. However, few, if any, such collaborations are ends in themselves. As the population changes and as information and service needs change, LIS education, including deans and directors and the requisite accrediting bodies, will need to reexamine the position and future direction of the field. These are exciting times for library and information science education and our graduates; we must make the most of them.

\section{Notes}

1. Judith Waldrop, "New Projections Show Faster Growth, More Diversity," American Demographics 15 (Feb. 1993): 9.

2. "Resident Population Projections, by Age and Sex: 1997 to 2050," in Statistical Abstract of the United States, 117th ed., no. 1717 (Washington, D.C.: Government Printing Office, 1997).

3. Marcia J. Nauratil, "Role Conflict in the Public Library," in Public Libraries and Nontraditional Clientele (Westport, Conn.: Greenwood Pr., 1985), 5.

4. Ibid., 31.

5. In 1889, the school, under the direction of Melvil Dewey, was moved to Albany and became the New York State Library School, where it remained until 1926. It then returned as the School of Library Service to what is now Columbia University. See Winifred B. Linderman, "Columbia University, School of Library Service," in Encyclopedia of Library and Information Science, vol. 5, ed. Allen Kent, Harold Lancour, and William Nasri (New York: Marcel Dekker, 1971), 370-90.

6. Michael H.Harris, "Foreword," in Melvil Dewey: His Enduring Presence in Librarianship, ed. Sarah Vann (Littleton, Colo.: Libraries Unlimited, 1977), 10. 85.

7. Wayne A. Wiegand, Irrepressible Reformer: A Biography of Melvil Dewey (Chicago: ALA, 1996),

8. Ibid., 48.

9. Robert Wedgeworth, "ALA and the Black Librarian: Strategies for the 70's," in The Black Librarian in America, ed. E.J. Josey (Metuchen, N.J.: Scarecrow Pr., 1970), 69.

10. The author received this information as a result of a conversation with Dr. Lotsee Patterson, Associate Professor SILS, University of Oklahoma, who may be the first American Indian LIS educator. Dr. Patterson earned her doctorate in 1979. [Telephone conversation with Patterson, May 21, 1998]. Also, for more detailed information, see Library and Information Science Education Statistical Report, ed. Timothy W. Sineath (Raleigh, N.C.: Association for Library and Information Science Education), published annually.

11. Timothy W. Sineath, "Faculty," in Library and Information Science Education Statistical Report 1996, ed. Timothy W. Sineath (Raleigh, N.C.: Association for Library and Information Science Education, 1996), 3.

12. E. J. Josey, "The Challenges of Cultural Diversity in the Recruitment of Faculty and Students from Diverse Backgrounds," Journal of Education for Library and Information Science 34 (fall, 1993): 303.

13. Timothy W. Sineath, "Faculty," in Library and Information Science Education Statistical Report 1993, ed. Timothy W. Sineath (Raleigh, N.C.: Association for Library and Information Science Education, 1993), 25.

14. — "Faculty" (1996), 28.

15. Jerry D. Saye, with Wen-Chen Lan, "Students," in Library and Information Science Education Statistical Report 1998, ed. Evelyn Daniel and Jerry D. Saye (Arlington, Va.: Association for Library and Information Science Education, 1998). (These data were acquired prior to publication; page number was unavailable.) 
16. Danny P. Wallace, "Students," in Library and Information Science Education Statistical Report 1996, ed. Timothy W. Sineath (Arlington, Va.: Association for Library and Information Science Education, 1996),142.

17. Academic and Public Librarians: Data by Race, Ethnicity E Sex, 1991 (Chicago: ALA, 1991), table 3 .

18. James C. Welbourne, "Achieving Black Economic Self-Reliance: The Urban Public Library Strengthens the Economic Base of its Community," in The Black Librarian in America Revisited, ed. E.J. Josey (Metuchen, N.J.: Scarecrow Pr., 1994), 124.

19. Lorna Peterson, "Strategies for Infusing Multicultural Education into the Library Science Curriculum," in Culture Keepers II: Unity through Diversity, Proceedings of the Second National Conference of African American Librarians, August 5-7, 1994, Milwaukee, Wis., ed. Stanton Biddle (Newark, N.J.: Black Caucus of the ALA, 1995), 75.

20. ALA, "News Fronts ALA," American Libraries 29, no. 6 (June/July 1998): 9.

21. See: E. J. Josey, "The Challenges of Cultural Diversity in the Recruitment of Faculty and Students from Diverse Backgrounds," Journal of Education for Library and Information Science 34 (fall 1993): 302-11; __ "Education for Library Services to Cultural Minorities," Education Libraries 15, no. 3 (winter 1991): 16-22; Major Owens, "The Specter of Racism in an Age of Cultural Diversity: The New Paradigm for African American Librarians," in Black Librarian in America Revisited, ed. E.J. Josey (Metuchen, N.J.: Scarecrow Pr., 1994), 286-97; Lorna Peterson, "Teaching the Practitioners: One Professor's Attempt at Library Education and Sensitivity to Multicultural Diversity," Reference Librarian 45/46 (1994): 23-28; Ismail Abdullahi, "Recruitment and Mentoring of Minority Students," Journal of Education for Library and Information Science 33, no. 4 (fall 1992): 307-10.

22. Veronica E. Nance-Mitchell, "A Multicultural Library: Strategies for the Twenty-First Century," College \& Research Libraries 57, no. 5 (Sept., 1996): 408.

23. Kathleen M. Heim, "Librarians for the New Millennium," in Librarians for the New Millennium (Chicago: ALA, 1988), 7.

24. Timothy W. Sineath, "Faculty," in Library and Information Science Education Statistical Report 1998, ed. Timothy W. Sineath (Washington, D.C.: Association for Library and Information Science Education, 1998), 16. The author is referring to, primarily, states located in the Southern Mountain, the Rocky Mountain, and portions of the Middle-West regions: Nevada, Utah, Idaho, Montana, Nebraska, North Dakota, South Dakota, Oregon, Wyoming, and Minnesota. 